\title{
ЗНАНИЯ О РАСТИТЕЛЬНОМ МИРЕ В ЯЗЫКОВОЙ КАРТИНЕ МИРА РУССКОГО НАРОДА
}

\section{Knowledge about the Plant World in the Language Picture of the World of the Russian People}

Keywords: junior schoolchildren, representations, language picture of the world, plants Contact: МГПУ; alya.aleksandrakozlova@mail.ru

Под языковой картиной мира понимают повседневные знания обо всем, что окружает человека, отраженные в системе языка, прежде всего в лексике. Языковая картина мира наивна, опирается на интуицию, здравый смысл. Эта картина мира не безальтернативна. «Научное исследование мира дает человечеству научную информацию, которая лежит в основании представлений, называемых научной картиной мира, дает руководящее направление научному мышлению и заключает в себе закономерности мироздания. Научная информация появляется в результате познания реальности и служит для дальнейшей познавательной работы человека, причем научная информация, как и сам язык, на котором она выражается, носит социальный характер» (Лихачев 2018: 93).

Изучение языковой картина мира находится в современном образовании на самом начальном этапе. Образование естественным образом осваивает новые научные идеи с некоторым отставанием. При всем этом, изучать языковую картину мира школьникам необходимо, так как язык сохраняет народную самобытность именно отражая в себе то видение окружающей действительности, которое традиционным образом существует в языке. Современные ученики все больше погружаются в виртуальный мир, чему способствует и привлекательность виртуальных игр и ресурсов, и их активная пропаганда и новые изменения в обществе, вызванные необходимостью карантина при распространении смертельно опасного заболевания. В такой ситуации ученик знает все меньше слов, называющих самые простые реалии из языковой картины мира. Приведем пример: девочка, посланная мамой в магазин за мясом, вернулась без покупки со словами: «Мяса нигде нет, везде написано говядина». Девочка не понимает, что 
к слову говядина на ценнике соответствует в обыденном языке гипероним мясо, который выступает в речи мамы качестве контекстного синонима. Можно утверждать, что знание языковой картины мира, которое у старших поколений, не погруженных в виртуальную жизнь, возникало спонтанно, у нового поколения должно быть целенаправленно сформировано. Если это не будет сделано, дети не только не смогут читать художественную литературу, изображающую реалии языковой картины мира, ни и не смогут решать насущные бытовые задачи.

Сознавая необходимость целенаправленного изучения младшими школьниками языковой картины мира, нужно отметить, что эта работа весьма обширна и сложна. Попытки изучать языковую картину мира в целом, то есть без специального отбора, материала приведут к размыванию материала. Вместо целостной картины школьники получат случайный набор не организованных фактов, хотя, может быть и интересный. При этом научная картина мира преподносится школьникам в целостном организованном виде.

В образовании младших школьников научная картина мира занимает все большее место, в ущерб естественным языковым представлениям. Школьников учат научным сведениям о природе, например, что «собственно мед в рационе медведя редок» (Лихачева 2018: 39), но это разрушает внутреннюю форму слова «медведь». Однако именно во внутренней форме слова сокрыты глубины истории языка, языковые представления о мире, языковая культура. Таким образом справедливыми оказываются слова Н. Д. Десяевой о том, что на последнем месте оказывается «формирование ответственности за языковую культуру как общечеловеческую ценность (Десяева 2016: 93).

Целенаправленный отбор материала для изучения языковой картины мира младшими школьниками может опираться на выделение лексико-семантических групп, тесно связанных с тематикой детской литературы. Наше внимание привлекла тематическая группа «растения», которая в русском языке с позиций обучения младших школьников еще не изучалась, хотя уже успела привлечь внимание исследователей как русского, так и других славянских языков с собственно лингвистической точки зрения. «В русском языке реалии растительного мира получали оценку с точки зрения их полезности, практики приготовления и возделывания, их вкусовых и других отличительных качеств: хрен и редька имеют горький вкус, перед использованием в пищу капусту рубят на мелкие части, при чистке лука от его запаха текут слезы, простейшими по способу приготовления блюдами на русском столе были отварная картошка и пареная репа и т. д.» (Шаймарданова 2019: 135). Мы видим, что при изучении языковой картина мира растения вызывают интерес с точки зрения их 
использования: лекарственного, кулинарного или декоративного. Необходимо отметить и другие направлений изучения лексической группы «растения»- связь с фольклором, в особенности паремиями, и изучение метафорического значения слов: «В русском устном народном творчестве рожь символизирует жениха, а пшеница - невесту. Сравните: В нашем жите хорош росток (о женихе); И в нашей пшенице нет торицы (о невесте). В русской языковой картине мира значима оппозиция рожь - пшеница, причем рожь символизирует общедоступность, общераспространенность, а пшеница - элитарность, доступность только для избранных (богатых). Пример: Матушка-рожь кормит всех дураков сплошь, а пшеничка по выбору» (Борисова 2018: 66).

Среди иных славянских языков, в которых исследована тематическая группа растения можно назвать, например, русинский - не самый широко распространенный и не являющийся государственным: «Виконане дослідження народних назв рослин русинів Пряшівщини дозволяє зробити такі висновки. Ботанічна лексика русинів становить велику за обсягом, давню щодо походження та цінну для лінгвістів, етнографів та істориків категорію слів у складі лексичного фонду мови русинів. 3 погляду прозорості внутрішньої форми, флороназви скласифіковано на немотивовані та мотивовані» (Гороф’янюк, 2018: 103).

Непосредственна цель нашего небольшого исследования - найти в лексическом поле «растения» примеры слов, которые помогут иллюстрировать различия языковой картиной мира и научной. Отобранные слова в дальнейшей работе должны быть использованы для разработки программы экспериментальной деятельности над формированием у обучающихся представлений о языковой картине мира. В нашей работе использованы лингвистический анализ текста и семантический анализ слова.

Структурирование и систематизация знаний далеко не всегда происходит на научной основе. Человек, получая знания из самых разных источников, подвергая эти знания и представления классификации на разных основаниях, создает разные модели (картины) мира, актуальные для той или иной сферы своей деятельности. «Освоение языковой картины мира требует внимания к тонкостям и глубине смысла слов, но начать можно с работы над словарными значениями» (Лихачев 2017: 17). 


\section{1. Кулинарные представления и биологические понятия о плодах}

В хозяйстве съедобные растения делят на фрукты, ягоды, овощи, орехи, зерновые. Эта классификация ненаучна, но она и должна быть такой в рамках нашего исследования, так как сама языковая картина мира носит не научный, а бытовой характер.

При рассмотрении категории «фрукты» следует оговориться, что она выделяется не во всех картинах мира. Так, в научной картине мира (в ботанике) понятия фрукт не существует, поэтому в терминологическом аппарате биологии, медицины и агрономии при описании тех или иных плодовых культур лексическая единица фрукт не используется, сама категория фрукты не выделяется. Однако слово фрукт весьма употребительно в экономике, торговле (внешней и внутренней), кулинарии, диетологии и бытовой речи.

Фрукт (лат. fructus - плод) - сочный съедобный плод дерева или кустарника, который содержит в себе одно или несколько семян растений.

Ягода тоже сочный плод. Фрукт отличается от ягоды в основном размером.

Овощи (слово также существует только в «бытовом» употреблении) - это любая часть растения, пригодная в пищу: корнеплод, лист, плод, клубень, луковица или стебель. Кулинарные книги могут относить к овощным растениям и отдельные виды грибов, например, шампиньоны, что противоречит естественнонаучной классификации.

Овощных растений насчитывается более 1200 видов.

В древнерусском языке слова «фрукт» не существовало, оно появилось лишь в 1705 году, раньше любые плоды назывались овощами (овоштами). К нам слово «фрукт» пришло из немецкого языка: Frucht (от латинского fructus - плод), так в старину называли «древесные плоды», например, яблоки и груши.

Не существует единой системы языковых представлений, которая бы соответствовала огромному разнообразию, существующему среди плодов растений.

\section{2. Народно-целительские приметы о растениях и научные представления}

Лечение травами обладает особым мистическим авторитетам у русского народа. До сих пор многие люди считают, что траволечение может быть более эффективным, чем средства современной медицины. Поэтому говоря о растениях в языковой картине мира нельзя не остановиться на целебных травах. 
Историк Иван Забелин писал, что в древности язычники относились к растениям как к живым существам: по поверьям, травы могли переходить с места на место, менять свой вид и внезапно исчезать, разговаривать между собой, кричать и плакать. Предки также верили, что у каждого растения был свой характер и нрав. Рвали травы в определенное время и в заповедных местах. Луга, опушки леса и болота с нужными растениями находили «знающие» люди. Растения собирали, соблюдая обряды: следовало «пасть ничком наземь и молить мать - сыру землю, чтоб она благоволила нарвать с себя всякого снадобья». Прежде чем сорвать цветок, его окружали с четырех сторон серебряными монетами, украшениями из драгоценных металлов или дорогой тканью. Не все растения показывались обычному человеку, чародейские травы давались в руки только знахарям, колдунам и ведунам.

Несмотря на подробные описания цветов и трав в этих сборниках, фольклористам довольно сложно опознать в чародейских снадобьях реальные растения и как-то их классифицировать. Травы и цветы имели множество разновидностей, часто одно и то же растение называли по-разному в зависимости от региона, и, наоборот, одно имя могли носить до десятка трав.

Часто в травниках упоминалась адамова голова. Это русское народное название ряда растений необычной формы, которым приписывались целебные или волшебные свойства. Считалось, что растение служило атрибутом колдунов и знахарей, его собирали ранним утром на Ивана Купалу. По поверьям, корень адамовой головы помогал увидеть затаившуюся нечисть, а человек, употребивший настой, «увидит», на ком лежит порча. Траве приписывали много чудесных свойств: она облегчала тяжелые роды, внушала храбрость воинам и помогала заживлять раны. Плотники брали ее с собой на высотные стройки церквей и палат, чтобы преодолеть страх высоты. Адамову голову вшивали в одежду для защиты от болезней или носили на цепочке на шее. Корень травы освящали святой водой, клали в церкви на 40 дней, а после носили с собой как оберег.

Еще одна магическая трава - нечуй-ветер или ястребинка волосистая из семейства сложноцветных. Свое название растение получило потому, что из-за невысокого роста недоступно действию ветров. Русский этнограф Иван Сахаров писал, что обладавший этой травой человек, по поверьям, мог остановить ветер на воде, избавить себя и судно от потопления и ловить рыбу без невода. Она росла зимой на берегах рек и озер, искали растение 1 января в полночь: верили, что в это время нечистая сила прогуливается по озерам и рекам и бросает магическую траву для усмирения бури. Обнаружить траву могли только слепые от рождения люди. 
Существует предположение, что это суеверие придумали бродячие слепцы, пользовавшиеся доверием простодушных крестьян.

Даже в академически признаваемой части траволечения нет терминологической строгости. Например, корни и корневища девясила не различают, вопреки научной строгости ботаники, и называют корнями даже на упаковке, продаваемой в аптеке.

В неортодоксальной народной медицине существует своя, забытая классификация растений: травы солнца и травы луны. Есть и сложные правила их сбора. Травы солнца собирают так: бессмертник - около полудня, девясил в начале августа, в полдень, зверобой - во второй половине лета до полудня, иванда-марью - перед восходом, мать-и-мачеху - на рассвете, пустырник - в полдень и т. д. Травы луны тоже собирают в определенное время: аир болотный - сразу после заката солнца, ландыш - на восходящем солнце по утренней росе, подорожник (лист) - во время цветения, по вечерней росе и т. д. Кроме того для всех растений определено время сбора по фазам луны. Выделяются и растения разных планет.

Конечно, все это суеверия, хотя отдельные правила вероятно могут быть научно обоснованными. Например, в полдень трава суше и собирать ее хорошо для дальнейшего высушивания. Но сточки зрения культуры ценна сама романтика поверий, человек во все времена нуждался в красивых выдумках, фантазировал и верил в фантазии. Поэтому плохо, что поверья о целебных травах уходят из языковой картины мира младшего школьника.

\section{3. Комнатно-растениеводческие и научные представления о растениях}

В комнатном растениеводстве цветы - это растения, а в науке - генеративные органы. Папоротник, который цветет только в народных поверьях, тоже называют цветком. В языковой картине мира растения что-то любят или не любят. Например, Ванька мокрый (бальзамин) любит воду. В научных представлениях растения не обладают эмоциями. Выводковые почки каланхоэ в языковой картине мира - это «детки», то есть процесс вегетативного размножения в языке тоже представляется одушевленно.

В языковой картине мира существует много названий растений, которые содержат и во внутренней форме слова, и в лексическом значении суеверные представления, не имеющие отношения к науке, но имеющие культурную ценность, как увлекательная игра, позволяющая компенсировать 
психологическое напряжение. Плющ (хойя) суеверно называют «мужегоном», ведь он якобы гонит из дома мужчин. Денежное дерево (толстянка) приносит в дом деньги. Тещин язык (сансевиерия), вопреки стереотипам о теще, укрепляет семейные узы и оберегает от ссор. Такие поверья даже детьми не воспринимаются всерьез, но связаны с ценностью семьи и несут младшему школьнику положительную информацию.

Научные названия многих растений и сложны для произношения и не имеют интригующей мистической ассоциации. Поэтому повседневные названия стоит сохранять. Как уже отмечено выше для сохранения этих названий необходимо специально изучать с младшими школьниками языковую картину мира, целенаправленно отбирая тематически сгруппированный материал. Результатом настоящей статьи стало появление способного заинтересовать младших школьников материала о таком актуальном для начального обучения фрагменте языковой картины мира, как знания о растениях. Результаты настоящей статьи предполагается использовать в дальнейшем в практике педагогической деятельности.

\section{Summary}

The language picture of the world is understood as the daily knowledge of everything that surrounds a person. The result of our research is the body of examples of words and expressions whose lexical meaning is not identical to the concept of a scientific nature. Based on the study of the meaning and conceptual content of this corpus of words, it is possible to form younger students' ideas about the language picture of the world of Slavic peoples. The scientific names of many plants are difficult to pronounce and have no intriguing mystical association. Therefore, everyday names are worth saving.

\section{Литература}

Борисова, Л. В. Кластер «культурные растения» в языковой картине мира. Вестник Московского университета. Серия 22: Теория перевода. 2018 (3), c. $65-79$.

Гороф'янюк, І. В. Народні назви рослин як фрагмент Мовної картини світу русинів. Русин. 2018 (52/2), с. 89-106.

Десяева, Н. Д. Современная языковая ситуация и ее отражение в содержании обучения русскому языку. In: Десяева, Н. Д. (ed.) Актуальные вопросы 
методики преподавания русского языка и русского языка как иностранного. Москва: Спутник+, 2016, с. 91-97.

Лихачев, С. В. Основы научной коммуникации. Учебное пособие для студентовбакалавров. Москва: Экон-информ, 2018.

Лихачев, С. В. Формирование у младших школьников представлений о языковой картине мира. Начальная школа. 2017 (1), с. 16-19.

Лихачева, Т. С. Соотношение русской языковой картины мира и научных представлений (на примере концептов диких животных). In: Уланович, О. И. (ed.) Языковая личность и эффективная коммуникация в современном поликультурном мире. Сборник статей по итогам III Международной научно-практической конференции. В двух частях. Часть 2. Минск: Издательский центр БГУ, 2018, с. 38-43.

Савенков, А. И. Эффективная организация исследовательского обучения школьников. Народное образование. 2011 (6), с. 173-181.

Шаймарданова, Г. М. Этнокультурная семантика фразеологизмов с названиями растений в русской и башкирской языковой картине мира. Вестник Башкирского государственного педагогического университета им. М. Акмулль. 2019 (50/2), с. 134-137. 